\title{
Nigel Morgan and Stella Panayotova, with the Assistance of Rebecca Rushforth (eds.). Illuminated Manuscripts in Cambridge: A Catalogue of Western Book Illumination in the Fitzwilliam Museum and the Cambridge Colleges. Part Four: The British Isles. Volume One: Insular and Anglo-Saxon Manuscripts c.700-c.1100. London/Turnhout: Harvey Miller/Brepols, 2013, 360 pp., 440 colour illustrations, $€ 175.00$.
}

Reviewed by: Helmut Gneuss, Ludwig-Maximilians-Universität München E-Mail: helmut.gneuss@anglistik.uni-muenchen.de

Cambridge is a rich source for the study of illuminated manuscripts in the Medieval West, and in particular for Insular and Anglo-Saxon manuscripts, as was demonstrated in the impressive exhibition of The Cambridge Illuminations in 2005, while the holdings of the Cambridge libraries - the University Library, the College libraries, and the Fitzwilliam Museum - represent a substantial share in the volumes of the great Survey of Manuscripts Illuminated in the British Isles (19751996). For Anglo-Saxon manuscripts in the Colleges and the Fitzwilliam Museum, ${ }^{1}$ we now have the comprehensive treatment in the present volume, which forms part 4.i of A Catalogue of Western Book Illumination in the Fitzwilliam Museum and the Cambridge Colleges, of which Part 1 (The Frankish Kingdoms, the Netherlands, Germany, Bohemia, Hungary and Austria), Part 2 (Italy and the Iberian Peninsula), each with two volumes, and Part 3, vol. 1 (France: c.1000-c.1250) have already appeared. The following volumes of Part 4 (The British Isles) for the period after 1100 are in preparation, and so is Part 5 covering "Illuminated Incunabula".

The first volume for the British Isles, here to be reviewed, is a splendid book in folio size, profusely illustrated with high-quality colour reproductions of folios, or details from folios, of all the manuscripts described and discussed. The bulk of the volume is devoted to 94 manuscripts from England, ranging from the early eighth to the end of the eleventh century, and, in a few cases, to the beginning of the twelfth. There are in addition one manuscript of Irish origin, and two from Wales (259-274). A section with Addenda to Part One of the work follows (275-322); it is a very welcome supplement to this volume, as eleven of the thirteen items it contains had found their way from France to England, probably or certainly even before the twelfth century. A few of the 94 English manuscripts are now owned by Pembroke (4), Clare (3), and St. John's (2), one each by Peterhouse, Sidney Sussex

1 The holdings of the University Library have been separately treated by Binski and Zutshi (2012). 
College and the Fitzwilliam Museum. By far the majority belong to the great collections of Corpus Christi College (44) and Trinity College (38), where they owe their preservation there to Matthew Parker's bequest of his books to Corpus Christi, and to the generous donations to Trinity College by John Whitgift, Archbishop, and Thomas Nevile, Dean of Canterbury, and to Roger Gale, all conveniently surveyed by Simon Keynes in an earlier exhibition catalogue (1992: 2). The order of the 94 English manuscripts is chronological. As was to be expected, most were written in the tenth (25) or eleventh century, only five antedate the tenth. As for the places or areas of their origin, it is impossible to generalize, with not a few cases of Anglo-Saxon (and, indeed, medieval) books whose origin remains uncertain or controversial. Almost all the 94 manuscripts come from the South or the Midlands. That nearly fifty certainly or presumably originated in one of the houses in Canterbury may not be surprising, but this no doubt largely depends on the provenance of the donations to Trinity College. The certain or possible origin of thirteen manuscripts at Worcester seems noteworthy. Two scriptoria not active before the eleventh century are represented, Bury St Edmunds (3 manuscripts) and Exeter (7). Only three books may have come from Winchester.

The descriptions of the manuscripts form the core of the book (17-258 for the 94 English manuscripts). There are no general introductions like the eleven very helpful chapters in The Cambridge Illuminations (2005), but these were meant for a somewhat different readership, and the attentive reader of the present book, including the competent specialist, will find himself or herself richly rewarded by the structure and contents of the entries, especially the thorough and exhaustive sections with "Comments".

All entries are accompanied by excellent colour plates, which will be appreciated by art historians and palaeographers alike. Each entry begins with a brief indication of contents, followed by information on language, place or area of origin, date, foliation, codicology, binding, secondo folio and script. The following section, on "Contents", where necessary for complex books, can be highly detailed, as e.g. for MS CCCC 201 (94-95). Under “Decoration” the authors supply detailed descriptions of miniatures, drawings, Canon Tables, framed incipits, historiated initials etc., followed by "Ornamentation", dealing mainly with initials and some cases of display script. "Provenance" records among other things listing in medieval library catalogues and, in particular, ownership of a book since the sixteenth century. This is followed by "Comments", then a section about the exhibitions where the manuscript was previously shown, and finally a full record of the pertinent scholarly literature on the manuscript (very extensive e.g. for the Prudentius in CCCC 23; no. 27, on p. 84).

Not a few readers of the book will find the "Comments" the most interesting and valuable part of the individual entries, which in not a few cases even make 
fascinating reading. In these sections the authors deal with various points of importance for our understanding of the history and study of a book, its ownership and contents, its type and tradition of script and decoration, etc. A few examples must suffice: a possible interpretation of the well-known frontispiece in CCCC 183, essentially differing from the established view (no. 9, p. 35); the discussion of the Utrecht Psalter style, and of the origin of CCCC 23 (no. 27, pp. 83-84); the analysis of the development and sources of the pontifical in CCCC 146 (no. 31, p. 92); the treatment of obvious links with the Continent in the decoration of Pembroke MS 201 (no. 51, pp. 153-155); the clearing up of the confusion about the origins of the two parts of Trinity College 0.2.51 (no. 81, pp. 224-225); the excellent inventory and discussion of the Durham copy of the Collectio Lanfranci in Peterhouse MS 74 (no. 83, pp. 230-234). The volume is provided with an extensive bibliography and several indexes that help to make the wealth of scholarship contained in the entries accessible, among them a detailed index of "Iconographic and Ornamental Motifs", recording e.g. all cases of foliage motifs, of interlace, and of zoomorphic motifs. An Index of "Provenance" includes under "Institutional Owners" references to all places of origin attributed to manuscripts in the book.

Finally, a few suggestions. CCCC 178 (no. 40, p. 121): For the Rule of St Benedict, the references to Gretsch 1978 are erroneous; they should have been to Gretsch 1974, and preferably to Gretsch 1973. - Trinity College B.15.34 (no. 47, pp. 143-144): The Psalter copied by Eadui is London, BL, MS Arundel 155 (now, incidentally, thoroughly treated by Dominik Kuhn, 2014); cf. also the Index on p. 355. - CCCC 191 (no. 50, p. 150): For the edition of the Rule of Chrodegang in Latin and Old English, the reference should have been to Langefeld 2003, 163-339, which supersedes Napier 1916. - CCCC 265 (no. 54, pp. 163-164): There is an excellent chapter on the manuscript, and an edition of Elfric's Letter to the Monks of Eynsham, with translation and very good commentary, by Christopher Jones (1998). - CCCC 391 (no. 55, pp. 165-169): The manuscript was introduced, the complete hymnal was collated and partly edited, and its musical notation discussed, by Inge Milfull (1996). Ebersberger 1999: Heidelberg (Bibliography, p. 330).

This book is an outstanding scholarly achievement and a treasury of early insular art. We are looking forward to seeing the future, forthcoming volumes of A Catalogue of Western Book Illumination in the Fitzwilliam Museum and the Cambridge Colleges for the British Isles and France. 


\section{Works Cited}

Alexander, J. J. G. (gen. ed.). 1975-1996. A Survey of Manuscripts Illuminated in the British Isles. 6 vols. in 9. London: Harvey Miller.

Binski, Paul and Stella Panayotova (eds.). 2005. The Cambridge Illuminations: Ten Centuries of Book Production in the Medieval West. London: Harvey Miller. [Exhibition catalogue].

Binski, Paul and Patrick Zutshi. 2012. Western Illuminated Manuscripts: A Catalogue of the Collection in Cambridge University Library. Cambridge: Cambridge University Press.

Gretsch, Mechthild. 1973. Die Regula Sancti Benedicti in England und ihre altenglische Übersetzung. Münchener Universitätsschriften. Texte und Untersuchungen zur Englischen Philologie 2. München: Fink.

Gretsch, Mechthild. 1974. " Athelwold's Translation of the Regula Sancti Benedicti and its Latin Exemplar”. Anglo-Saxon England 3: 125-151.

Jones, Christopher A. 1998. Alfric's Letter to the Monks of Eynsham. Cambridge Studies in AngloSaxon England 24. Cambridge: Cambridge University Press.

Keynes, Simon. 1992. Anglo-Saxon Manuscripts and Other Items of Related Interest in the Library of Trinity College, Cambridge. Old English Newsletter Subsidia 18. Binghamton, NY:

CEMERS, State University of New York.

Kuhn, Dominik. 2014. Der lateinisch-altenglische Libellus precum in der Handschrift London, British Library, Arundel 155. Münchener Universitätsschriften. Texte und Untersuchungen zur Englischen Philologie 41. Frankfurt am Main: Lang.

Langefeld, Brigitte. 2003. The Old English Version of the Enlarged Rule of Chrodegang, Edited together with the Latin Text and an English Translation. Münchener Universitätsschriften. Texte und Untersuchungen zur Englischen Philologie 26. Frankfurt am Main: Lang.

Milfull, Inge B. 1996. The Hymns of the Anglo-Saxon Church: A Study and Edition of the Durham Hymnal. Cambridge Studies in Anglo-Saxon England 17. Cambridge: Cambridge University Press.

Morgan, Nigel and Stella Panayotova (eds.). Illuminated Manuscripts in Cambridge: A Catalogue of Western Book Illumination in the Fitzwilliam Museum and the Cambridge Colleges. London: Harvey Miller.

Part One. 2009. The Frankish Kingdoms, the Netherlands, Germany, Bohemia, Hungary and Austria. 2 vols. [251 MSS].

Part Two. 2012. Italy and the Iberian Peninsula. 2 vols. [400 MSS].

Part Three. 2015. France. Volume One: c.1000-c.1250.

Part Four. 2013. The British Isles. Volume One (with Rebecca Rushforth): Insular and AngloSaxon Manuscripts c.700-c.1100. [97 MSS and Addenda].

Napier, Arthur S. (ed.). 1916. The Old English Version of the Enlarged Rule of Chrodegang together with the Latin Original. EETS OS 150. London. 